\begin{tabular}{|c|c|c|}
\hline \multirow[t]{2}{*}{$\underline{\mathrm{DE}}$} & $\begin{array}{l}\text { DE GRUYTER } \\
\text { OPEN }\end{array}$ & ECONOMIC THEMES (2016) 54(1): 21-44 \\
\hline & & DOI 10.1515/ethemes-2016-0002 \\
\hline
\end{tabular}

\title{
ECONOMIC CRISIS AND THE NATURE OF ENTREPRENEURIAL AND MANAGEMENT ACTIVITIES
}

\author{
Božidar Leković \\ University of Novi Sad, Faculty of Economics Subotica, Republic of Serbia \\ 凶bolesu@ef.uns.ac.rs \\ Slobodan Marić \\ University of Novi Sad, Faculty of Economics Subotica, Republic of Serbia \\ $\bowtie$ marics@ef.uns.ac.rs
}

UDC
005.961:005.
914.3]:338.1
24.4
Original
scientific
paper

Received:

07.04.2015

Accepted:

11.04.2016

\begin{abstract}
The essential research intention in this work is oriented toward considering the nature of entrepreneurial activities regarding to the volume of representation, according to some stages of the entrepreneurial process for defined groups of countries, different development degree in crisis conditions. The analysis of research data has drawn some conclusions, which have largely confirmed hypotheses. Obtained results, after the application of adequate statistical procedures, emphasize the existence of negative correlation, degree of economic development and the rate of economic growth. They are partly explained by the place and causes of analysed crisis circumstances, the degree of integrity of financial and economic systems, as well as the heterogeneous economic structure, as the main resistance to negative economic trends. The defined groups of countries of different development degrees show different differences in all the degrees of the entrepreneurial process. There is a positive correlation between the volume of entrepreneurial activities and the rate of economic growth, but on behalf of the countries of the lower development degree. Crisis conditions in the least developed countries generate an additional pressure on entrepreneurial activities; while the relatively stable environment of highly developed countries enables some individuals to find business possibilities outside the entrepreneurial sector.

Key words: economic crisis, entrepreneurship, economic development, economic conditions, GEM project

JEL classification: M13, M21
\end{abstract}

This paper represents a part of research of stated authors within the international GEM project, whose results were published within a comprehensive study for the period of research. 


\section{Introduction}

Economic and system business conditions completely determine the entrepreneurial environment, which, as an external factor, represents a significant component in the process of decision-making on starting a new business project, but in further stages of the entrepreneurial process, too. The environmental conditions (Doern, 2009) in the form of potential barriers relate to the crisis of the institutions, undefined political, legal and financial framework where the cited sector exists and the series of other aggravating circumstances, which drastically exert influence and create entrepreneurial activities, intentions and attitudes. If these barriers are minimal, the chances of entrepreneurial sector to realize expansion to all dimensions are bigger. In the previous research, numerous advantages and benefits of this sector have been identified. It plays the vital role in the process of transition, enabling the exit from recession; as the driving force of growth, it generally makes a stronger economy by creating new jobs and innovations. Therefore, every obstacle, on the road in the form of the cited barriers, leaves irreparable consequences (Wells et al., 2003). Business ambient causes and determines successfulness of entrepreneurial activities, i.e. the factors that define the business ambient can be positive or negative power in forming entrepreneurial intentions and they belong to external processes being outside the control of individuals and, being such, they do not form only the role of entrepreneurial projects, but also their strategy and the measure of success (Leković \& Marić, 2012).

The central research aim connected with determining the volume and structure of entrepreneurial activities, to individual phases of the entrepreneurial process (entrepreneurial process is defined by the GEM methodology) in the countries of different degree of economic development, in the conditions of crisis.

Consequently, in the study set the following research objectives:

- In order to determine the direction and strength of connection between the attained degree of economic development and the degree of GDP percent change, as the indicator of economic growth or fall;

- To identify differences of defined groups of countries, the different development degree depending on percent change of GDP as the indicator of economic growth or fall;

- Identify difference of defined groups of countries, the different development degree depending on the volume of entrepreneurial activities, according to all the phases of the entrepreneurial process;

- In order to determine the direction and strength of connection between the volume of the attained degree of economic development and the volume of entrepreneurial activities, according to all the phases of the entrepreneurial process. 
The research methodology involves the use of parametric procedures due to the characteristics of the selected variables and the number of observations in the sample. It will be used univariate procedures ANOVA and Pearson $r$ coefficient of linear correlation in order to determine the direction and strength of connection will apply. The application of the chosen methodology is aimed to determine the characteristics of each subsample (a group of countries) potential differences, boundaries, distance and homogeneity in order to make appropriate conclusions.

The entrepreneurial sector experienced verification of its value, the role and importance of economic growth and development, therefore it was identified as an important economic resource serving to reach many development goals, necessary to be managed in order to provide direct benefit for national wealth. Stimulation and development of entrepreneurship and entrepreneurial behaviour is one of the basic elements of economic policy of most countries, disregarding to the degree of development. To create a favorable economic environment, the state is responsible at all the levels (Smallbone et al., 2010) and it should provide appropriate institutional, legal and cultural framework as the external environment is one of the basic conditions to develop entrepreneurship, both in transitional countries and in the countries of developed market economics (Smallbone \& Welter, 2001b).

Many implemented research projects, studies, as well as scientific works of eminent authors in this field have confirmed the close connection of entrepreneurial activities and the degree of economic development of a national economy. This connection was exposed and analyzed in the framework of one the most comprehensive global studies on entrepreneurship; it is the GEM project. Obtained results confirmed causality. The reached degree of economic development represents the general indicator of economic and system conditions of an economy, being, according to the methodology of the World Economic Forum and measured by GDP per capita in US\$ PPP Basis is appropriate for comparative analyses. This indicator was one of the main indicators for classifying countries in three phases of economic development (Schwab, 2009). It was also taken over in the same form for the need of realizing the GEM project. GDP per capita does not only reflect the economic conditions of an economy, but it is also the expression of social, cultural and other circumstances existing in some region and it directly forms attitudes and intentions of an individual relating to, firstly, entrepreneurial behaviour. Therefore, every change of these circumstances, caused by the growth or fall of the reached development degree, significantly influences on the change of perception of the environment of an individual, stimulating or limiting his/her inclinations and concrete activities. Thus, the fall of economic activities, in the form of economic crisis, directly exerts influence on the change of the whole society. Because of these changes and newly created critical circumstances, the 
overall entrepreneurial environment changes, and it causes the changes in entrepreneurial attitudes, intentions and activities. The changes of entrepreneurial behaviour in crisis conditions show in the change of the size and structure of entrepreneurial activities during all the phases of entrepreneurial processes because of its hyperactive sensibility on economic circumstances.

\section{Entrepreneurship and the Conditions of Economic Crisis}

To represent and understand better the phenomenon of entrepreneurship, we should not go further from the Austrian school of economists, starting from J. Schumpeter to the near past. Thanks to P. Draker, the continuity of quality analysis and the importance of entrepreneurship in economic trends have been successfully held. The strong orientation of the Austrian school and Draker's interest in the strategic implications of entrepreneurship can be explained by one unusual fact, in the way outside of the framework of scientific analysis. J. Schumpeter was a regular guest with the Draker's parents, in the dining room in Vienna (Kiessling \& Richey, 2004).

Connection of entrepreneurship and economic trends has become explicit and the present results of numerous contemporary and current studies and researches as GEM projects point to it. Traditional analyses of economic growth did not provide an observed place and role of entrepreneurs, entrepreneurship and entrepreneurial processes in its creation (Bosma \& Levie, 2009). Economic growth and development were mostly explained by numerous factors, both economic and non-economic (Bleaney \& Nishiyama, 2002), without direct connection with entrepreneurship. Historically, the biggest contribution in developing entrepreneurship theory and its role is ascribed to J. Schumpeter, the Austrian economist. According to him, entrepreneurship is the driving force of all economic changes disturbing the current state and causes creative destruction. It is evident that many economists emphasize the big importance of entrepreneurship for economic growth, especially in critical situations, in both developed countries and developing countries, as well as a means to solve development problems of transitional countries (Giamartino, 1991). Economic governance during transition is an innovative process: it is impossible to follow a uniform approach or to use the same growth model in order to achieve the same results (Starkevičiute, 2011). The sector of small and medium-sized enterprises (SMEs) and entrepreneurship is cited as the most efficient instrument for the transformation of the former socialist countries, from centrally planned to market economies (Smallbone \& Welter, 2001a). The enhancement of total competitive ability in the transitional economies requests the creation of a modern knowledgebased economy, the sustainable economic growth and the enlargement of the country's economic competitiveness (Buracas, et al., 2012). That development of the features of entrepreneurship's expression depends on economic 
transformations also is related to new innovation, technologies, and knowledge used (Greblikaite \& Krisciunas, 2012).

However, even highly developed countries do not renounce this development lever, formally determine for it in their strategic documents. Therefore, the European Union selected the SMEs sector and entrepreneurship for sets goal as one of the strategies. All these development directives, EU defined by the European charter for small enterprises. It was accepted at the European Council in Santa Maria da Feira, Portugal, 19-20 June 2000, initiated by the European Commission and Declaration (signed in Maribor, Slovenia, 23 April 2003). It was on the policy obligatory for all the candidate countries for $\mathrm{EU}$ accession to give help in realizing the goals of the EU (UNECE, 2000-2001).

A well-developed sector of SMEs and entrepreneurship provides many benefits to an economy, both in ripe market economies (Aidis, 2005) and those countries being at the start of this process. Not all of this means that the entrepreneurship in less developed countries, in this case, transitional countries, should be discouraged for their contribution to economic development because of the identified environmental limits; on the contrary, small businesses and entrepreneurial projects represent the driving force to go through crises and the factor of economic stabilization in transitional countries (Leković et al., 2014). It means that there is no difference between the role of entrepreneurship and characteristics of this sector relating to the level of economic development reached in the country (Smallbone \& Welter, 2001a).

One current and comprehensive concept of entrepreneurship is represented by the GEM conceptual model, which clearly points to essential prerequisites for developing entrepreneurial activities at all the levels, as well as the results and their economic importance. We can notice from the model that the current business activities are present as already established enterprises, mostly dependent from the general national environments, while new business projects are directly restricted by entrepreneurial conditions of the environment (Reynolds et al, 2005). All this points to those entrepreneurial activities depend on a different set of parameters relating to existing business activities. The model represents two different business processes based and supported by arguments of scientists in the field of entrepreneurship, mostly from the Austrian School, including Schumpeter (1934), Kirzner (1997), and other economists who recognized the role of entrepreneurship in economic development as Leibenstein (1968), Baumol (2003), and Acs and other (2004). Basically, both sets of conditions can be found as a social, cultural and political context or the socio-cultural and political limitations as Leibenstein calls them. These fundamental factors can understand national culture or universal values (Smith, Petersen \& Schwartz, 2002), national wealth in the sense of the Government's capability to support directly the entrepreneurial environment or the kind of political and economic system. Further, these circumstances can 
refer to the population growth (Hunt \& Levie, 2004) and the rate of economic growth (Lundstrom \& Stevenson, 2005). The second part of the model represents the relationship of entrepreneurship and economic growth by means of two separated business processes based on different conditions. It is indisputable that Schumpeter was the first economist to connect entrepreneurs with economic growth, who freed himself from the prevailing approach of comparative statistics and recognized economy as a self-transforming system with the entrepreneur as an agent of changes (Schumpeter, 1934). Schumpeter represents entrepreneurs as innovators who create conditions for profit acquiring, creating a temporary monopoly by means of organizational and technological innovations. By their activities, they constantly disturb the current balance state, preferred by existing business actors, forcing them to react to newly created threats. This process of creative destruction (Schumpeter, 1934) is manifested in improving productivity, as well as bigger economic growth. This approach was advanced and developed further by Leibenstein (1968), Baumol (2003) and Acs and others (2004) who, as the last in the series, developed a new growth theory, with the explicit role of Schumpeter's entrepreneur as the transformer of knowledge in economic knowledge and significant participant of economic growth. Schumpeter's entrepreneur disturbs the state of economic balance through the process of innovations, while the alternative consideration of entrepreneurship and economic growth came from the second part of Austrian economists as Ludwig von Mises (1949), Hayek (1978) and Kirzner (1997). They emphasize the role of entrepreneur as an inventor of favorable market conditions, citing that "every participant is always an entrepreneur in every real and living economy" (Mises, 1949, Kirzner, 1997). It follows that the basic question is not who entrepreneurs are, but what they do, with what conditions and what consequences.

Many authors draw conclusions that Schumpeter's and Kizner's approaches are more complementary than contradictory (Baumol, 2003; Shane, 2003), while the entrepreneurs of both approaches are the participants of economic growth, anyway. By its conceptual framework, the GEM model of the entrepreneurial environment included Schumpeter's innovative entrepreneur and Kirzner's predominantly replicative one. Thus, Schumpeter's entrepreneur is unusual with small chances to exert big influence on economic growth, while Kirzmer's entrepreneur is usual and has bigger chances for small influence on economic growth (Levie \& Autio, 2008).

Similar to Schumpeter, Leibenstein identifies two basic kinds of business activities that take part in economic growth. One is routine entrepreneurship or management that includes the activities connected with coordination and management of existing business systems. The other is new activities or nascent entrepreneurship that means the activities necessary for creating or moving enterprises to markets that have not existed up to now or have not been clearly defined. 
The existing model suggests that those who believe that have the skills, knowledge and motivation to start business projects, recognizing necessary conditions, should take new business activities. Individuals must recognize possibilities before taking any activities. Factors exerting influences on business activities in general, as formal education, are represented in the model with general national business conditions, while the factors making the specific framework of entrepreneurial activities, as entrepreneurial training, and are represented as entrepreneurial conceptual conditions. The previous model emphasizes general entrepreneurial conditions, which directly influence on generating the volume and nature of entrepreneurial activities.

Draker (1985) has also the previous standpoints and he does not try to lessen the importance of entrepreneurship as met-economic event. To his opinion, some other forms of innovations should be considered as entrepreneurial ones, as some original innovator can make some faults that can be identified and removed with entering the market by some other actors. $\mathrm{He}$ calls this type of innovations creative imitation. Draker's broader view on entrepreneurship has been considerably accepted in the last 30 years by most management theoreticians. It is now recognized as a critical factor, which determines the long-term strategic success in competition with other organizations. It is reflected in the capabilities of enterprises to be more innovative, more flexible and capable to answer the fast market changes.

The connection between entrepreneurship and economic development is supported in developed countries, as in the U.S.A. in the second part of the 20 s (Birch, 1987). SMEs and entrepreneurship play an important role in all economies and they are key generators of employment and income, as well as the creators of innovations and growth (Bobera et al., 2014). In the OECD, SMEs employ more than a half labor in the private sector. In the EU, they include over $99 \%$ of all enterprises. Besides, $91 \%$ of these enterprises are micro enterprises with less than ten workers. Regarding to their importance in all economies, they are of substantial importance for economic revival, too (OECD, 2009). It is certain that large enterprises played the leading role in the development of developed countries. However, during the 1970s with the appearance of crises (1973-1974, 1978-1979), they showed their weakness and impossibility to adapt to new situations. Developed countries found their way out just in small business capacities, which, in these situations, successfully amortized crisis shocks. Thanks to such big flexibility and innovativeness, small businesses adapted faster and better to new economic situations.

From the previously cited, we can express the importance and role of entrepreneurial dimension in the business environment of the global character. The mentioned characteristics of the environment, thinking of the process of globalization and development of the entrepreneurial sector in the economic structure, initially developed together in the period of the 1970s and 1990s of 
the last century. Developmental foundations were also the same, and they related to the appearance and spreading information and communication resources. It is obvious that the globalization and integration processes influence the development of national economies and increase the level of competition; thereby they place a greater emphasis on development factors, which should increase their competitiveness (Kraft \& Kraftova, 2012). Krugman represented the idea of entrepreneurship as the story on individuals: the people who acquired capital working in their garages or kitchens. In the middle of the 19 century, proponents of the free market, and the values of unlimited entrepreneurship, had a problem with the image. When they said the private entrepreneurship, they thought mostly of the General Motors; when they said the businessman, they thought of the people in the gray flannel suits. However, in the 1990s of the last centuries, there was the idea that wealth was the result of virtue or even creativity (Krugman).

The statements and great optimism of contemporary economists relating to cyclical economic trends discourage or, to say better, is more surprising. Treating economic depression as the problem of the past is solved; therefore, the only thing that remains in macroeconomic theory is concentration on the long-term economic growth, instead of accepting crisis periods as regular social phenomena. It is something that calls attention of the professional public. Beside the Great Depression (1929 -1930) considered as useless economic tragedy as the consequence of Herbert Hoover's ${ }^{2}$ folded arms and the approach of cleaning balances and financial decay, today, a number of economists agree that it was the consequence of the fall of effective demand, therefore it could be surmounted by direct financial intervention of the Federal Reserve System. Further, crisis in the form of stagflation in the 1970s caused the change of the Keynes' model of state interventionism bringing market on the stage, as an almighty invisible hand to regulate economic trends in the form of neoliberalism. Besides, in the 1990s, the crisis of significant proportion and the Asian group of countries with Japan at the head encouraged some people, as Robert Lukas, Professor at Chicago University and the Nobel Prize winner for economics in 1995, to state their opinion with great optimism (at the annual meeting of the American Economic Association in 1993) that the problem of prevention of depression was solved. Therefore, it was only necessary to concentrate on the subject of the long-term economic growth (Krugman, 2010). After several years later, there appeared the crisis of the biggest proportion ever recorded, its start is connected with 2008, and it is ascribed to the breakdown of the US financial market. The global financial crisis was triggered and fuelled by factors which were transgressions of dharma. Thus, the solution to prevent such a crisis is adherence to dharma (Sivakumar \& Krishnaswami, 2011)

\footnotetext{
${ }^{2}$ President of the U.S.A. from 1929 to 1933
} 
The last crisis definitely affixed its seal on the business ambient and entrepreneurship development. Determinants of the environment in recession conditions moved in the direction of financial indebtedness of governments in the countries seized by crisis, the price increase of indebtedness because of increased risk, budget deficit growth. Because of decreasing fiscal incomes and the fall of economic activities, liquidity crisis in the real sector, unemployment growth, significant oscillation of exchange rates, as well as different speculative trends in financial markets, there was a sufficient reason to start deep changes within existing economic trends The interplay of financial industry organizations and formal and informal institutions is key to understanding the creation of the crisis (McDonnell \& Burgess, 2013). All these negative entries of recession largely endanger small enterprises for the following reasons:

- Reduction of the number of employees as a measure is impossible because a small number of employees is there;

- Low degree of diversity relating to business activities:

- Weaker financial structure (capitalization level);

- Low or insufficient credit rating;

- Big credit dependence;

- Fewer possibilities for financing;

- Liquidity crisis, they bear big supplies very hard;

- In the global flows, they are mostly endangered by big enterprises (OECD, 2009).

This crisis certainly contributed to closing many small businesses and the failure of many entrepreneurial projects, decreasing the volume of business and profit, and unemployment increase. Labor market condition becomes a main determinant of entrepreneurship. Bigger unemployment rate, as one of the indicators of unemployment, stimulated the creation of new jobs through the process of self-employment and starting new business projects (Fairlie, 2011). The relation between the environment and entrepreneurial strategies suggest that entrepreneurial environment can be recognized according to the characteristics as dynamism, heterogeneity and enmity that can influence on entrepreneurial perception, which, in return, can induce entrepreneurs to adapt some strategic orientations in the direction of innovativeness, proactivity and risk taking (Tan, 1996). Therefore, entrepreneurship represents the leading indicator of economic cycles (Schumpeter); it means that entrepreneurship is dependant on economic trends (GEM Report 2010).

The economic ambient determines labor conditions for small businesses that can be exploited (Davidson, 1989). Numerous researches analyze economic circumstances through the influence of location, economic branches and market on the efficiency of small businesses. The characteristics of one environment can be represented by the degree of economies of scale (Audretsch, 1995), trade 
union organizations of workers within the economic branch (Acs \& Audretsch, 1990), as well as the possibilities of introducing innovations (Vivarelly \& Audretsch, 1998). All this can exert influence on the growth of small businesses. The same, it is known, that the growth of small businesses is conditioned by the growth of economic branches (Audretsch \& Mahmood, 1994) and market maturity (Baldwin \& Gellatly, 2003). The previous analyses of economic conditions relate to the aggregate level; it means that the environment has some influence on all small businesses in some economic branches, markets and locations. The results of previous researches point out that small growing businesses try to advance profitability and widen market niches (Storey, 1996), which are to narrow and look insufficiently defined from the aspect of goals, economic branches and the wideness of the market. Just this can be an advantage in defining economic circumstances of small businesses, to different dimensions, which are the consequence of subjective perception of the owners of small businesses and they include heterogeneity, enmity, dynamism, the structure of consumers and competition (Pelham \& Wilson, 1995). The dynamism of the environment is characterized by instability and the continuity of changes, where growth possibilities appear because of social, political, technological and economic changes. The hostile environment is a generator of danger for the enterprise through competition development or the reduction of demand for the enterprise's products, and it will significantly decrease the possibilities of growth for a small enterprise. Heterogeneity of the environment understands its complexity, meaning the existence of different market segments with different characteristics and needs within the same economic branch. However, heterogeneous markets are much more acceptable for small businesses with a view of finding and developing specific market niches in relation to markets where demand is homogeneous.

The entrepreneurial context is mostly characterized by dynamism and changes. It means that entrepreneurs in such conditions, because of their flexibility, adapt better than large business systems. Entrepreneurial projects with their continual foundation and fall create an imbalance or the state of disequilibrium where they cope with better, competing successfully in some situations and the enterprises much bigger and stronger than they are. To some economists (Schumpeter), the lack of entrepreneurial activities, innovation first, is the basic cause of crises in the economy. The current economic crisis, known as the Global economic recession (2008), as well as other forms of crisis role, can represent the stimulating circumstances for the creation and development of entrepreneurial projects. It is because new business possibilities appear in the processes of big market oscillation, in the form of new markets and available resources representing ideal chances for creation, survival and development of the entrepreneurial sector. 


\section{Data and Methodology}

\subsection{Data and variables}

The results of researching the GEM project in 2009 represent the basic data source of analyzed characteristics (variables). The criterion to choose the country to come into the sample was the availability of data to selected variables, participants in the GEM project in 2009. The basic criterion for the selected year of observation, 2009 in this case, is evidently the cited recession in relation to the previous years 2007 and 2008, i.e. crisis circumstances of the economic ambient within which the volume and structure of entrepreneurial activities are researched.

The countries were classified into three phases of economic development, according to the WEF methodology, as explained in GCI (Global Competitiveness Report 2009 - 2010), based on the Factor-driven economies, as the countries of the lowest development stage, Efficiency-driven economies, as the countries of the medium development stage, and Innovation-driven economies, as the group of the most developed countries.

The source of data for the characteristics of the degree of economic development, as well as economic growth is the International Monetary Fund, World Economic Outlook Database, October 2010.

The degree of economic development is GDP per capita in US\$ on PP Basis, being at the same time the basis to classify countries according to the phases of economic development.

The change of the GDP level, as the indicator of fall (economic crisis) or the increase of economic activity is expressed as $\Delta$ GDP as percent change, as the indicator of crisis intensity.

The characteristic with the indication suboan (Nascent entrepreneur: Involved in setting up a business) is an entrepreneurial activity in the phase of the entrepeneurial process where entrepreneurs appear as individuals who are owners or managers of new business now who engaged resources and realize some kind of income up to three months.

The characteristic babybu (Owner-manager of young business - up to 3.5 years old) represents individuals, the carriers of entrepreneurial activities in the form of owners or managers who realize some kind of income in the period less than 3.5 years.

The characteristic with the indication of TEA (Total Early-Stage Entrepreneurial Activity) index represents the main indicator of the volume of the entrepreneurial activities of the last phase within this study and it includes the previous two indicators. 
The characteristic estabbu (Owner - manager of an established business more than 3.5 years old) represts the indicator of entrepreneurial activities in the last phase of the entrepreneurial process and it includes individuals who in the form of owners or entrepreneurs realize some income more than 3.5 years of doing business.

The characteristic anybus (Overall Entrepreneurial Activity) includes entrepreneurial activities from the previous three phases.

\subsection{Hypotheses and methodology}

The central research question connected with determining the volume and structure of entrepreneurial activities, to individual phases of the entrepreneurial process (entrepreneurial process is defined by the GEM methodology) in the countries of different degree of economic development, in the conditions of crisis. Available data on selected characteristics enable carrying out analyses to determine differences between the countries of different development degree, according to all the phases of the entrepreneurial process, as well as mutual connections and relationships of observed degrees of economic development, economic crisis and entrepreneurial activities. The number of observations in the sample (number of participant countries of the GEM project, 2009) enables and suggests the application of parameter statistical techniques, which will enable carrying out more precise and exact conclusion because of its sensibility.

What we want to emphasize with the results of research and it will represent the basis for all the next analyses is the relationship of the level change of economic development expressed by the GDP percent change and the attained degree of economic development expressed by GDP per capita in US\$. Taking into consideration the cause and place of appearance of the current World economic crisis, as well as the global connectivity of the world, primarily financial and economic systems depending on the attained degree of economic development, we are exposing the first hypothesis:

H1: There is a negative correlation between the attained degree of economic development and the degree of GDP percent change, as the indicator of economic growth or fall.

H1a: There is statistically a significant difference of defined groups of countries, the different developmental degree depending on percent change of $G D P$ as the indicator of economic growth or fall.

Hypothesis $\mathrm{H} 1$ will be tested by the Pearson $\mathrm{r}$ coefficient of linear correlation in order to determine the direction and strength of connection between the degree of economic development and GDP percent change. The difference between the group of countries of different development to the degree of growth or fall degree will be tested by the variance analysis - the ANOVA method. 
H2: There is statistically a significant difference of defined groups of countries, the different developmental degree depending on the volume of entrepreneurial activities, according to all the phases of the entrepreneurial process. Stability, as well as the significance of this difference, will be tested by variance analysis.

H3: There is a negative correlation between the volume of the attained degree of economic development and the volume of entrepreneurial activities, according to all the phases of the entrepreneurial process.

H3a: There is a positive correlation between the volume of entrepreneurial activities according to all the phases of the entrepreneurial process and change percent of GDP.

Hypothesis H3, as well As H3a will be tested by the Pearson $r$ coefficient of linear correlation in order to determine the direction and the strength of connection between selected characteristics.

\section{Results of Researches and Analyses}

Based on the analyses of previously exposed attitudes, we can notice that the role and characteristics of entrepreneurial activities in all the phases of economic development are identical, but different forms of entrepreneurship and the structure of entrepreneurial activities are different depending on the attained development degree of an economy (Sternberg and Wannekers, 2005). Further, we can draw a conclusion that some changes, as fall (economic crisis) or the growth of economic activities, change business ambient, and so indirectly influence on the kind and structure of entrepreneurial activities. Also, testing hypothesis $\mathrm{H} 1$ gave results illustrated in Table 1, which confirm the hypothesis and the existence of medium negative correlation and Pearson's coefficient points to $\mathrm{r}=-0.408$. It means the higher development level of the country measured by GDP per capita in US\$, the lower GDP percent change, i.e. it is negative after some level. The medium values of observed characteristics confirm such a connection between these two characteristics, where GDP change in highly developed countries in the form of medium value amounts to $3.8 \%$ and it confirms the existence of deep crisis. In the group of countries of the lowest development degree, economic growth is realised at the level of medium values of $2.3 \%$. This disparity in the rate of economic growth to significantly negative, and the negative correlation of these two characteristics, can be explained by the place and the sample of crisis, degree of global integrity of national financial and economic systems, the degree of international financial dependence of countries. In addition, it can be seen from the results that follow, the bigger volume of entrepreneurial activities according to all the phases of the entrepreneurial process, forms a heterogeneous economic structure with fewer number of large enterprises, which, in crises, shows some level of flexibility and gives a better answer to hard business circumstances. 
Table 1. Correlation of economic development and crisis dimension

\begin{tabular}{llrr}
\hline & & $\begin{array}{c}\text { GDP per } \\
\text { Capita } \\
\text { in USD PPP } \\
\text { Basis }\end{array}$ & $\begin{array}{c}\Delta \text { GDP } \\
\text { as percent change }\end{array}$ \\
\hline GDP per Capita & Pearson Correlation & 1 &,$- 408^{* *}$ \\
in USD PPP Basis & Sig. (2-tailed) & 48 &, 004 \\
& $\mathrm{~N}$ &,$- 408^{* * *}$ & 48 \\
\hline$\Delta$ GDP & Pearson Correlation &, 004 & 1 \\
as percent change & Sig. (2-tailed) & 48 & 48 \\
\hline$* *$ Correlation is significant at the 0.01 level (2-tailed). & & \\
\hline
\end{tabular}

Source: Authors' calculation

The results of the ANOVA analysis in Table 2 confirm the hypothesis H1a, i.e. they point to the existence of statistically significant difference between groups of countries of different degree of development in relation to the characteristic $\triangle \mathrm{GDP}$ as a percent change. Interpreting the results of the manysided comparison between defined groups of countries to observed characteristic, we can see that the difference is statistically significant only between the countries with the lowest and highest development degree, i.e. the degree of economic development; therefore, because of that the current economic circumstances generated significant difference at the rate of economic growth.

Table 2. Results of the ANOVA analysis of observed characteristics to define groups of countries

\begin{tabular}{llrrrrr}
\hline & & $\begin{array}{c}\text { Sum of } \\
\text { Squares }\end{array}$ & df & $\begin{array}{c}\text { Mean } \\
\text { Square }\end{array}$ & F & Sig. \\
\hline suboan & Between Groups & 263,195 & 2 & 131,597 & 12,251 &, 000 \\
& Within Groups & 483,366 & 45 & 10,741 & & \\
& Total & 746,561 & 47 & & &, 000 \\
\hline babybu & Between Groups & 249,474 & 2 & 124,737 & 11,463 & \\
& Within Groups & 489,688 & 45 & 10,882 & &, 000 \\
& Totabal & 739,162 & 47 & & & \\
\hline TEA & Between Groups & 933,470 & 2 & 466,735 & 16,231 &, 044 \\
& Within Groups & 1294,020 & 45 & 28,756 & & \\
& Total & 2227,490 & 47 & & &, 000 \\
\hline estabbu & Between Groups & 123,936 & 2 & 61,968 & 3,359 & \\
& Within Groups & 830,143 & 45 & 18,448 & &, 007 \\
& Total & 954,080 & 47 & & & \\
\hline anybus) & Between Groups & 1600,146 & 2 & 800,073 & 11,148 & \\
& Within Groups & 3229,557 & 45 & 71,768 & & \\
& Total & 4829,703 & 47 & & & \\
\hline \multirow{2}{*}{ GDP } & Between Groups & 214,070 & 2 & 107,035 & 5,610 & \\
& Within Groups & 858,590 & 45 & 19,080 & & \\
& Total & 1072,660 & 47 & & & \\
\hline
\end{tabular}

Source: Authors' calculation 
Results of the ANOVA analysis illustrated in Table 2 and the coefficient value $p<.05$ preliminary confirm the existence of statistically significant difference to all the characteristics of entrepreneurial activities and refer to the analysis of results of many-sided comparison (Table 3) to determine the difference between the countries and for observed characteristics. Countries of the lowest development degree named as Factor - driven economies show the high degree of entrepreneurial activities, in the domain of medium value, in all the phases of the entrepreneurial process (suboan $=10,1663$, babybu $=9,6350$, TEA $=19,0275$, estabbu $=11,1150$, anybus $=29,3150$ ) and statistically significant difference to all the phases of entrepreneurial process in relation to the last groups of countries. The significant difference, as well as the high level of entrepreneurial activities, in countries of the lowest development degree, can be explained by the pressure of the high unemployment rate, instability of the institutions, weak social protection, as well as relatively small number of large enterprises, where entrepreneurship and self-employment becomes necessity, and, very often, the only chance. The group of countries classified as the medium development level, named Efficiency driven - economies, show statistically significant difference in the groups of countries of the lowest and highest development degrees in the starting phase of the entrepreneurial process (suboan), as in the TEA indicator that also includes the previous activities. It means that the economic ambient as a determinant of the degree of economic development generates significant differences in the phase of starting an entrepreneurial project (suboan), in crisis conditions, too, pointing to that these activities are at the significant lowest level relating to highly developed countries. It is the consequence of small pressure on self-employment and entrepreneurial orientation because of stable and much bigger business possibilities outside the entrepreneurial sector, as well as significant measures of stabilization of taken by the side of government institutions in order to crisis recovery. The countries of the medium development level do not show a statistically significant difference to the indicators babybu, which shows entrepreneurial activities to 3.5 years of doing business and anybus as the indicator of the overall entrepreneurial activities. It can point to some phase of stabilization of the economic ambient of the given group of countries.

The volume of entrepreneurial activities of selected characteristics within some groups of countries of different development degrees, as well as drawn conclusions based on results of the ANOVA analysis, tables 2 and 3 confirm the results of correlation analysis in Table 4 and so the $\mathrm{H} 3$ hypothesis, i.e. the existence of negative strong correlation between the degree of economic development and the volume of entrepreneurial activities to all the phases is confirmed, except for the estabbu indicator, which relates to entrepreneurs with business more than 3.5 years, and where a weaker connection of the same direction is present, i.e. at the level medium strong negative correlation as a significant difference between only the groups of countries of the lowest and highest development degree is shown within the ANOVA analysis in this indicator. 
Table 3. Multiple comparison of the groups of countries to observed variables

\begin{tabular}{|c|c|c|c|c|c|c|c|}
\hline \multirow{3}{*}{$\begin{array}{c}\text { Dependent } \\
\text { Variable }\end{array}$} & \multirow{3}{*}{$\begin{array}{l}\text { (I) Level of } \\
\text { Development } \\
\text { Country }\end{array}$} & \multicolumn{4}{|c|}{ Tukey HSD } & \multirow{2}{*}{\multicolumn{2}{|c|}{$\begin{array}{l}\text { 95\% Confidence } \\
\text { Interval }\end{array}$}} \\
\hline & & \multirow{2}{*}{$\begin{array}{l}\text { (J) Level of } \\
\text { Development } \\
\text { Country }\end{array}$} & \multirow{2}{*}{$\begin{array}{c}\text { Mean } \\
\text { Differenc } \\
\mathrm{e} \\
(\mathrm{I}-\mathrm{J})\end{array}$} & \multirow{2}{*}{$\begin{array}{l}\text { Std. } \\
\text { Error }\end{array}$} & \multirow[b]{2}{*}{ Sig. } & & \\
\hline & & & & & & $\begin{array}{l}\text { Lower } \\
\text { Bound }\end{array}$ & $\begin{array}{l}\text { Upper } \\
\text { Bound }\end{array}$ \\
\hline \multirow{7}{*}{ suboan } & \multirow[b]{2}{*}{$\begin{array}{l}\text { Factor Driven } \\
\text { Economies }\end{array}$} & $\begin{array}{l}\text { Eficiency Driven } \\
\text { Economies }\end{array}$ & $4,02339^{*}$ & 1,36168 & ,014 &, 7232 & 7,3236 \\
\hline & & $\begin{array}{l}\text { Innovation } \\
\text { Driven } \\
\text { Economies }\end{array}$ & $6,75520^{*}$ & 1,38131 & ,000 & 3,4074 & 10,1030 \\
\hline & \multirow{3}{*}{$\begin{array}{l}\text { Efficiency } \\
\text { Driven } \\
\text { Economies }\end{array}$} & $\begin{array}{l}\text { Factor Driven } \\
\text { Economies }\end{array}$ & $-4,02339^{*}$ & 1,36168 & ,014 & $-7,3236$ &,- 7232 \\
\hline & & Innovation & & & & & \\
\hline & & $\begin{array}{l}\text { Driven } \\
\text { Economies }\end{array}$ & $2,73180^{*}$ & 1,03771 & 031 & ,2168 & 5,2468 \\
\hline & \multirow{2}{*}{$\begin{array}{l}\text { Innovation } \\
\text { Driven } \\
\text { Economies }\end{array}$} & $\begin{array}{l}\text { Factor Driven } \\
\text { Economies }\end{array}$ & $-6,75520^{*}$ & 1,38131 & ,000 & $10,1030^{-}$ & $-3,4074$ \\
\hline & & $\begin{array}{l}\text { Efficiency Driven } \\
\text { Economies }\end{array}$ & $-2,73180^{*}$ & 1,03771 & ,031 & $-5,2468$ &,- 2168 \\
\hline \multirow{7}{*}{ babybu } & \multirow[b]{2}{*}{$\begin{array}{l}\text { Factor Driven } \\
\text { Economies }\end{array}$} & $\begin{array}{l}\text { Efficiency Driven } \\
\text { Economies }\end{array}$ & $4,50167^{*}$ & 1,37056 &, 006 & 1,1800 & 7,8234 \\
\hline & & $\begin{array}{l}\text { Innovation } \\
\text { Driven } \\
\text { Economies }\end{array}$ & $6,65184^{*}$ & 1,39032 & ,000 & 3,2823 & 10,0214 \\
\hline & \multirow{3}{*}{$\begin{array}{l}\text { Efficiency } \\
\text { Driven } \\
\text { Economies }\end{array}$} & $\begin{array}{l}\text { Factor Driven } \\
\text { Economies }\end{array}$ & $-4,50167^{*}$ & 1,37056 & ,006 & $-7,8234$ & $-1,1800$ \\
\hline & & Innovation & & & & & \\
\hline & & $\begin{array}{l}\text { Driven } \\
\text { Economies }\end{array}$ & 2,15018 & 1,04447 &, 110 &,- 3812 & 4,6816 \\
\hline & \multirow{2}{*}{$\begin{array}{l}\text { Innovation } \\
\text { Driven } \\
\text { Economies }\end{array}$} & $\begin{array}{l}\text { Factor Driven } \\
\text { Economies }\end{array}$ & $-6,65184^{*}$ & 1,39032 &, 000 & $10,0214^{-}$ & $-3,2823$ \\
\hline & & $\begin{array}{l}\text { Efficiency Driven } \\
\text { Economies }\end{array}$ & $-2,15018$ & 1,04447 & , 110 & $-4,6816$ & ,3812 \\
\hline \multirow{7}{*}{ TEA } & \multirow{2}{*}{$\begin{array}{l}\text { Factor Driven } \\
\text { Economies }\end{array}$} & $\begin{array}{l}\text { Efficiency Driven } \\
\text { Economies }\end{array}$ & $7,95655^{*}$ & 2,22797 &, 002 & 2,5568 & 13,3563 \\
\hline & & $\begin{array}{l}\text { Innovation } \\
\text { Driven } \\
\text { Economies }\end{array}$ & 12,78803 & 2,26008 & ,000 & 7,3105 & 18,2656 \\
\hline & \multirow{3}{*}{$\begin{array}{l}\text { Efficiency } \\
\text { Driven } \\
\text { Economies }\end{array}$} & $\begin{array}{l}\text { Factor Driven } \\
\text { Economies }\end{array}$ & $-7,95655^{*}$ & 2,22797 & ,002 & $\begin{array}{r}- \\
13,3563\end{array}$ & $-2,5568$ \\
\hline & & Innovation & & & & & \\
\hline & & $\begin{array}{l}\text { Driven } \\
\text { Economies }\end{array}$ & $4,83148^{*}$ & 1,69788 & ,018 &, 7165 & 8,9465 \\
\hline & \multirow{2}{*}{$\begin{array}{l}\text { Innovation } \\
\text { Driven } \\
\text { Economies }\end{array}$} & $\begin{array}{l}\text { Factor Driven } \\
\text { Economies }\end{array}$ & 12,78803 & 2,26008 &, 000 & $18,2656^{-}$ & $-7,3105$ \\
\hline & & $\begin{array}{l}\text { Efficiency Driven } \\
\text { Economies }\end{array}$ & $-4,83148^{*}$ & 1,69788 &, 018 & $-8,9465$ &,- 7165 \\
\hline
\end{tabular}




\begin{tabular}{|c|c|c|c|c|c|c|c|}
\hline \multirow{6}{*}{ estabbu } & $\begin{array}{l}\text { Factor Driven } \\
\text { Economies }\end{array}$ & $\begin{array}{l}\text { Eficiency Driven } \\
\text { Economies } \\
\text { Innovation } \\
\text { Driven } \\
\text { Economies }\end{array}$ & $4,62237^{*}$ & 1,81022 & ,094 &,- 5161 & 9,0096 \\
\hline & Efficiency & $\begin{array}{l}\text { Factor Driven } \\
\text { Economies }\end{array}$ & $-3,80881$ & 1,78449 & ,094 & $-8,1337$ & ,5161 \\
\hline & Driven & Innovation & & & & & \\
\hline & Economies & $\begin{array}{l}\text { Driven } \\
\text { Economies }\end{array}$ & ,81356 & 1,35992 &, 822 & $-2,4824$ & 4,1095 \\
\hline & $\begin{array}{l}\text { Innovation } \\
\text { Driven }\end{array}$ & $\begin{array}{l}\text { Factor Driven } \\
\text { Economies }\end{array}$ & $-4,62237^{*}$ & 1,81022 &, 037 & $-9,0096$ &,- 2351 \\
\hline & Economies & $\begin{array}{l}\text { Efficiency Driven } \\
\text { Economies }\end{array}$ &,- 81356 & 1,35992 &, 822 & $-4,1095$ & 2,4824 \\
\hline \multirow{6}{*}{ anybus } & Factor Driven & $\begin{array}{l}\text { Efficiency Driven } \\
\text { Economies }\end{array}$ & 11,29738 & 3,51973 & ,007 & 2,7669 & 19,8279 \\
\hline & Economies & $\begin{array}{l}\text { Innovation } \\
\text { Driven } \\
\text { Economies }\end{array}$ & 16,84026 & 3,57047 &, 000 & 8,1868 & 25,4937 \\
\hline & Efficiency & $\begin{array}{l}\text { Factor Driven } \\
\text { Economies }\end{array}$ & 11,29738 & 3,51973 &, 007 & 19,8279 & $-2,7669$ \\
\hline & $\begin{array}{l}\text { Driven } \\
\text { Economies }\end{array}$ & $\begin{array}{l}\text { Innovation } \\
\text { Driven } \\
\text { Economies }\end{array}$ & 5,54288 & 2,68231 &, 108 &,- 9580 & 12,0438 \\
\hline & $\begin{array}{l}\text { Innovation } \\
\text { Driven }\end{array}$ & $\begin{array}{l}\text { Factor Driven } \\
\text { Economies }\end{array}$ & $\begin{array}{r}16,84026 \\
*\end{array}$ & 3,57047 &, 000 & 25,4937 & $-8,1868$ \\
\hline & Economies & $\begin{array}{l}\text { Efficiency Driven } \\
\text { Economies }\end{array}$ & $-5,54288$ & 2,68231 &, 108 & $12,0438^{-}$ & ,9580 \\
\hline \multirow{6}{*}{$\Delta \mathrm{GDP}$} & Factor Driven & $\begin{array}{l}\text { Efficiency Driven } \\
\text { Economies }\end{array}$ & 3,66596 & 1,81481 & ,119 &,- 7324 & 8,0644 \\
\hline & Economies & $\begin{array}{l}\text { Innovation } \\
\text { Driven } \\
\text { Economies }\end{array}$ & $6,09941^{*}$ & 1,84097 &, 005 & 1,6376 & 10,5612 \\
\hline & $\begin{array}{l}\text { Efficiency } \\
\text { Driven }\end{array}$ & $\begin{array}{l}\text { Factor Driven } \\
\text { Economies } \\
\text { Innovation }\end{array}$ & $-3,66596$ & 1,81481 & ,119 & $-8,0644$ & ,7324 \\
\hline & Economies & $\begin{array}{l}\text { Driven } \\
\text { Economies }\end{array}$ & 2,43344 & 1,38303 & ,195 &,- 9185 & 5,7854 \\
\hline & $\begin{array}{l}\text { Innovation } \\
\text { Driven }\end{array}$ & $\begin{array}{l}\text { Factor Driven } \\
\text { Economies }\end{array}$ & $-6,09941^{*}$ & 1,84097 &, 005 & 10,5612 & $-1,6376$ \\
\hline & Economies & $\begin{array}{l}\text { Efficiency Driven } \\
\text { Economies }\end{array}$ & $-2,43344$ & 1,38303 & ,195 & $-5,7854$ & ,9185 \\
\hline
\end{tabular}

Source: Authors' calculation 
Table 4. Correlation between entrepreneurial activities and the degree of economic development and the level of Crisis

\begin{tabular}{|c|c|c|c|c|c|c|}
\hline & & suboan & babybu & TEA & estabbu & anybus \\
\hline \multirow{3}{*}{$\begin{array}{l}\text { GDP per Capita } \\
\text { in USD (PPP } \\
\text { Basis) }\end{array}$} & Pearson Correlation &,$- 509^{* *}$ &,$- 509^{* *}$ &,$- 569^{* *}$ &,- 282 &,$- 498^{* *}$ \\
\hline & Sig. (2-tailed) &, 000 &, 000 &, 000 &, 052 &, 000 \\
\hline & $\mathrm{N}$ & 48 & 48 & 48 & 48 & 48 \\
\hline \multirow{3}{*}{$\begin{array}{l}\Delta \mathrm{GDP} \\
\text { as percent } \\
\text { change }\end{array}$} & Pearson Correlation &, $389^{* *}$ &, $557^{* *}$ &, $524^{* *}$ & $449^{* *}$ &, $539^{* *}$ \\
\hline & Sig. (2-tailed) &, 006 &, 000 &, 000 &, 001 &, 000 \\
\hline & $\mathrm{N}$ & 48 & 48 & 48 & 48 & 48 \\
\hline
\end{tabular}

Source: Authors' calculation

As for the derived H3a hypothesis, it is also confirmed. It can be proved by available results in Table 4 in the form of a strong positive correlation of the volume of entrepreneurial activities, to all the phases of the entrepreneurial process and the rate of economic growth in crisis conditions. We can draw the conclusion that the countries having the bigger volume of entrepreneurial activities also have the bigger rate of economic growth. In this case, it is characteristic for the countries of the lower development degree. This result can be partly explained by the fact that a more heterogeneous economic structure with a large number of entrepreneurial projects and a small number of large enterprises is more flexible and resistant on economic falls, as well as the fact that the significant entrepreneurial sector provides a more stable contribution to economic results in less developed countries.

\section{Conclusion}

Entrepreneurial ambient in the conditions of crisis is exposed to significant changes in the form of redistribution, especially in highly developed countries because of the influence of the recession, a significant quantity of economic resources is free, as well as some market segments and it represents new favorable circumstances for entrepreneurial activities of the most capable individuals. Significant stable environment of highly developed countries in the conditions of crisis, with significant state interventionism, gives a wide range of business opportunities. It lessens the pressure on entrepreneurial aspirations and self-employment, then, it contributes to greater success of new entrepreneurial projects, as well as safer survival of existing small businesses.

We have in this study achieved the following research results:

- By correlation analysis, we confirm hypothesis H1, that mean the higher development level of the country measured by GDP per capita in US\$, the lower GDP percent change, i.e. it is negative after some level. 
- Results of the ANOVA analysis confirm the hypothesis H1a, i.e. they point to the existence of statistically significant difference between groups of countries of different degree of development in relation to the characteristic $\Delta \mathrm{GDP}$ as a percent change.

- The volume of the entrepreneurial activities of selected characteristics within some groups of countries of different development degrees, as well as drawn conclusions based on the results of the ANOVA analysis and confirm the results of correlation analysis and so the $\mathrm{H} 3$ hypothesis, i.e. the existence of negative strong correlation connection between the degree of economic development.

Also, our results of research are providing answers to all the objectives set in the introduction:

- There is a negative and a medium strong connection between the economic development and the degree of GDP as a percent change;

- Strength of the crisis depends by level of economic development of the defined group of countries;

- The scope of the entrepreneurial activities by the phases of entrepreneurial process is statistically significantly different between groups of countries;

- There is a negative and a medium strong connection between the economic development and scope of the entrepreneurial activities by the phases of the entrepreneurial process.

Less developed countries (WEF, GCR) are characterized by a big volume of entrepreneurial activities in all stages of the entrepreneurial process, as entrepreneurship becomes a necessity because of the instable economic ambient. However, because of a large number of small enterprises and a small number of large enterprises, the heterogeneous economic structure exists, demonstrating big flexibility and resistance to crisis shocks; the positive rate of economic growth confirms it. The positive rate of economic growth with the group of countries of the lowest degree of economic development in the period of observation is the consequence of distance and weak connections with the epicenter of the last World economic crisis, which is still relevant.

The previous conclusions of this research can be interpreted by Draker's attitude (1985), built within the Austrian economic school. It relates to economic trends, with general economic trends. Similar to the current recession conditions, we can cite the example of the postwar market conditions, which, although temporary, define the conditions of survival by the capability to use newly created possibilities. Such a behaviour is generally determined by managers' capabilities to act entrepreneurially exploiting innovations as the answer to significant market changes in the conditions of economic crisis. They appear mostly because of consumption reduction caused by income decrease or unemployment decrease. 


\section{References}

Acs, Z. J., \& Audretsch, D. B. (1990). The determinants of small-firm growth in US manufacturing. Applied Economics, 22(2), 143-153.

Acs, Z. J., Audretsch, D. B., Braunerhjelm, P. B., \& Carlsson, B. (2004). The Missing Link: The Knowledge Filter and Entrepreneurship in Endogenous Growth (No. 4783). CEPR Discussion Papers.

Aidis, R. (2005). Institutional Barriers to Small- and Medium-Sized Enterprise Operations in Transition Countries. Small Business Economics, 25, 305-318.

Audretsch, D. B. (1995). Innovation and Industry: Evolution. The MIT Press.

Audretsch, D. B., \& Mahmood, T. (1994). Firm selection and industry evolution: the post-entry performance of new firms. Journal of Evolutionary Economics, 4(3), 243-260.

Baldwin, J. R., \& Gellatly, G. (2003). Innovation strategies and performance in small firms. Edward Elgar Publishing.

Bartlett, D. (2008) Fallout of the Global Financial Crisis. World Economic Forum, 2008. Network of Global Agenda Councils. Summit on the Global Agenda, Dubai, United Arab Emirates 7-9 November 2008.

Baumol, W.J. (2003.) On Austrian analysis of entrepreneurship and my own. Austiran Economics and Entrepreneurial Studies, 6, 57-66, Amsterdam: Elsevier Science.

Birch, D. (1987). Job Creation in America. New York: Free Press.

Bleaney, M. \& Nishiyama, A. (2002). Explaining Growth: A Contest Between Models. Journal of Economic Growth, 7, 43-56.

Bobera, D., Lekovic, B., \& Berber, N. (2014). Comparative Analysis of Entrepreneurship Barriers: Findings from Serbia and Montenegro. Engineering Economics, 25(2), 167-176.

Bosma, N. \& Levie, J. (2009). Global Entreperneurship Monitor - 2009 Global Report. Babson College, Boston, USA, Universidad del Desarrollo, Santiago, Chile, Reykjavík University, Háskólinn Reykjavík, Iceland and London Business School, London UK.

Buracas, A., Zvirblis, A. \& Joksiene, I. (2012) Measurement of Entrepreneurship Macro Surrounding Advantages: Country's Economic Competitiveness Approach. Inzinerine Ekonomika-Engineering, 23(1), 5-13.

Davidsson, P. (1989). Continued entrepreneurship and small firm growth. Stockholm School of Economics. The Economic Research Institute.

Doern, R. (2009). Investigating Barriers to SME Growth and Development in Transition Environments A Critique and Suggestions for Developing the Methodology. International Small Business Journal, 27(3), 275-305.

Drucker, P.F. (1985). Innovation \& Entrepreneurship: Practice and Principles. New York: Harper \& Row.

Drucker, P. F. (1985). The effective executive. Franklin Webster Co.

Ekonomska komisija UN za Evropu (UNECE) Mala i srednja preduzeća u zemljama u tranziciji, dvogodišni pregled za period 2000-2001, str. 11. 
Fairlie, R., W. (2011). Entrepreneurship, Economic Conditions and Great Recession. Santa Cruz: University of California.

Giamartino, G. (1991) Will small business be the answer for developing economies? Journal of Small Business Management, 91-94.

Greblikaite, J., \& Krisciunas, K. (2012). The Development of Features of Entrepreneurship's Expression in an Enterprise. Engineering Economics, 23(5), 525-531.

Hayek, F. A. (1974). The Pretence of Knowledge. Nobel Memorial Lecture, Stockholm, 11 December. Hayek (1978).

Hunt, S. \& Levie, J. (2004). Culture as a predictor of entrepreneurial activity. Frontiers of Entrepreneurship Research, Babson Park, MA.

International Monetary Fund (2010) World Economic Outlook Database, October.

Kiessling, T.S. \& Richey, R.G. (2004). Examining the theoretical inspirations of a management guru: Peter F. Drucker and the Austrian School of Economics. Management Decision, 42(10), 1269 - 1283.

Kirzner, I. M. (1997). Entrepreneurial discovery and the competitive market process: An Austrian approach. Journal of economic Literature, 35(1).

Kraft, J., \& Kraftova, I. (2012). Innovation-Globalization-Growth (Selected Relations). Engineering Economics, 23(4), 395-405.

Krugman, P. (2010) Povratak ekonomije depresije i ekonomska kriza 2008. Smederevo: Heliks.

Leibenstein, H. (1968). Entrepreneurship and development. The American Economic Review, 72-83.

Leković B., \& Marić S. (2012). Uticaj globalne ekonomske recesije na obim i strukturu preduzetničkih aktivnosti. 17. Međunarodni naučni skup po nazivom: Strategic Management and decision support systems in strategic Management, Subotica: Ekonomski fakultet Subotica, 20 April, 2012, ISBN 978-86-7233-305-3, UDK: 005.52:658.114.1; 338.124.4(100).

Leković, B., Marić, S. \& Leković, B. (2014). Characteristics of Entrepreneurial Activities in Transitional Countries and Their Influence on Development. Inzinerine Ekonomika-Engineering Economics, 25(1), 62-71.

Levie, J., \& Autio, E. (2008). A theoretical grounding and test of the Gem model. Small Business Economics, 31(3), 235-263.

Lundstrom, A. \& Stevenson, L. (2005). Entrepreneurship Policy: Theory and Practice. New York: Springer-Verlag.

McDonnell, A., \& Burgess, J. (2013). The impact of the global financial crisis on managing employees. International Journal of Manpower, 34(3), 184-197.

Mises, L. V. (1949). 1998. Human Action: A Treatise on Economics.

Niels B., Zoltan J., Erkko A., Alicia C., \& Jonathan L. (2009). Global Entreperneurship Monitor - 2008 Global Report. Boston, USA: Babson College, Santiago, Chile: Universidad del Desarrollo, and London, UK: London Business School.

OECD Centre for Entrepreneurship (2009). SMEs and Local Development, The Impact of the Global Crisis on SME and Entrepreneurship Financing and Policy Responses. 
Pelham, A. M., \& Wilson, D. T. (1995). A longitudinal study of the impact of market structure, firm structure, strategy, and market orientation culture on dimensions of small-firm performance. Journal of the academy of marketing science, 24(1), 27-43.

Reynolds, P., N. Bosma, E., Autio, S. Hunt, N. De Bono, I. Servais, P. Lopez-Garcia, \& N. Chin, (2005). Global Entrepreneurship Monitor: Data Collection, Design and Implementation 1998-2003. Small Business Economics, 24, 205-231.

Rezultati istraživanja GEM projekta u Republici Srbiji za period 2007.- 2009. godine, GEM tim Ekonomskog fakulteta u Subotici, Univerziteta u Novom Sadu.

Schumpeter, J.A. (1934). The Theory of Economic Development. Cambridge, MA: Harvard University Press.

Schwab, K. (2009). Global Competitiveness Report 2009-2010. World Economic Forum. Geneva, Switzerland. Preuzeto sa: http://www.weforum.org/pdf/GCR09/ GCR20092010fullreport.pdf;

Shane, S. A. (2003). A general theory of entrepreneurship: The individual-opportunity nexus. Edward Elgar Publishing.

Sivakumar, N., \& Krishnaswami, S. R. (2011). Global financial crisis: dharmic transgressions and solutions. International Journal of Social Economics, $39(1 / 2), 39-54$.

Smallbone, D. \& Welter, F. (2001a). The Distinctiveness of Entrepreneurship in Transition Economies. Small Business Economics, 16, 249-262.

Smallbone, D. \& Welter, F. (2001b). The Role of Government in SMEs Development in Transition Economies. International Small Business Journal, 19, 63-77.

Smallbone, D., Welter, F. Voytovich, A. \& Egorov, I. (2010). Government and entrepreneurship in transition economies: the case of small firms in business services in Ukraine. The Service Industries Journal, 5, 655-670.

Smith, P. B., Peterson, M. F. \& Schwartz, S. H. (2002). Cultural Values, Sources of Guidance, and their Relevance to Managerial Behavior A 47-Nation Study. Journal of cross-cultural Psychology, 33(2), 188-208.

Starkevičiūtè, M. (2011). Transition towards new global setting in Lithuania. Ekonomika, 90(4), 34-48.

Storey, D. J. (1996). The ten percenters. London: Deloitte \& Touche.

Vivarelli, M., \& Audretsch, D. (1998). The link between the entry decision and postentry performance: evidence from Italy. Industrial and Corporate Change,7(3), 485-500.

Wells, B., Pfantz, T., \& Bryne, J. L. (2003) Russian Women Business Owners: Evidence of Entrepreneurship in a Transitional Economy. Journal of Development Entrepreneurship, 8, 59-71 


\section{EKONOMSKA KRIZA I PRIRODA PREDUZETNIČKIH I MENADŽMENT AKTIVNOSTI}

Apstrakt: Osnovna istraživačka namera ovog rada usmerena je na analizu prirode preduzetničkih aktivnosti u zavisnosti od obima i strukture preduzetničkog procesa u okviru definisanih grupa zemalja različitog stepena ekonomske razvijenosti u uslovima krize. Analiza rezultata istraživanja upućuje na zaključke koji u potpunosti potvrđuju postavljene hipoteze istraživanja. Rezultati istraživanja do kojih se došlo primenom odgovarajućih statističkih postupaka naglašavaju postojanje negativne korelacije stepena ekonomskog razvoja i stope ekonomskog rasta. Oni su delimočno objasnili mesto i uzroke analiziranih uslova krize, stepen integrisanosti finansijskog i ekonomskog sistema, kao heterogenu privrednu strukturu u vidu glavnog otpora prema negativnim ekonomskim trendovima. Definisane grupe zemalja rezličitog stepena razvijenosti ispoljavaju razlike $u$ svim fazama preduzetničkog procesa. Postoji pozitivna korelacija između obima preduzetničkih aktivnosti i stope ekonomskog rasta i to kod zemalja nižeg stepena razvijenosti. Uslovi krize u zemljama najnižeg stepena ekonomske razvijenosti generišu dodatni pritisak na preduzetničke aktivnosti, dok je relativno stabilno okruženje u visoko razvijenim zemljama pružilo mogućnosti određenom broju pojedinaca da realizuju poslovne mogućnosti izvan preduzetničkog sektora.

Ključne reči: ekonomska kriza, preduzetništvo, ekonomski razvoj, ekonomski uslovi, GEM projekat 


\section{Authors' biographies}

Božidar Leković is full professor at the Department of Management, Faculty of Economics Subotica, University of Novi Sad, Republic of Serbia, where he teaches bachelor's courses in Principles of Management, master's courses Performance Management and Contemporary Management, and Ph.D. courses Management Theory and Technologies. His research interests include Leadership, Communication, Human Resources, and Entrepreneurship. Besides his work at the Faculty, he has been engaged in the various national and international projects and activities in the fields of research, education, and development of curricula and syllabus for Management Study. He has authored numerous scientific and research articles in various kinds of publication.

Slobodan Maric is research assistant at the Department of Management, Faculty of Economics Subotica, University of Novi Sad, Republic of Serbia, where he teaches bachelor's courses in Principles of Management and master's courses Performance Management and Contemporary Management. He has taken part in many national and international scientific and research projects. In addition, he is author and coauthor of numerous scientific and professional papers in the fields of management, entrepreneurship, and project management. 